\title{
Impact of Urban Expansion on Superficial Water Quality in Periurban Areas
}

\author{
Adriana Schueler ${ }^{1}$, Vinicius Perrut dos Santos ${ }^{2}$, Decio Tubbs ${ }^{3}$ \\ ${ }^{1}$ Department of Architecture and Urbanism and Post Graduate Program in Territorial Development and Public Policies, \\ Universidade Federal Rural do Rio de Janeiro, Seropédica, Brasil \\ ${ }^{2}$ Engineering and Architecture Project Coordination from Universidade Federal Rural do Rio de Janeiro, Seropédica, Brasil \\ ${ }^{3}$ Department of Geoscience, Universidade Federal Rural do Rio de Janeiro, Seropédica, Brasil \\ Email:schueler.a@gmail.com,vprrut@gmail.com,dtubbs@uol.com.br
}

How to cite this paper: Schueler, A., dos Santos, V.P. and Tubbs, D. (2019) Impact of Urban Expansion on Superficial Water Quality in Periurban Areas. Journal of Environmental Protection, 10, 1591-1601. https://doi.org/10.4236/jep.2019.1012095

Received: November 25, 2019

Accepted: December 10, 2019

Published: December 13, 2019

Copyright $\odot 2019$ by author(s) and Scientific Research Publishing Inc. This work is licensed under the Creative Commons Attribution International License (CC BY 4.0).

http://creativecommons.org/licenses/by/4.0/ (c) (i) Open Access

\begin{abstract}
Economic growth promoted by large investment projects in the city of Seropédica and surrounding areas is not accompanied by a territorial planning that supports future growth scenarios. The challenge of the municipality is to prepare to have its territory fully transformed. This study aimed to establish quantitative data on the interferences that the growth model practiced has caused in its main watercourse called Valão dos Bois. For this, its morphometric characteristics and physicochemical parameters of water quality were measured, and computational simulations of the self-purification processes were performed at various points, as well as the infiltration and precipitation processes, surface flow and leaching in four occupation scenarios of the urbanized areas of the basin, for rains with five different return periods.
\end{abstract}

\section{Keywords}

Water Recourses, Urban Development, Computer Simulation, Sanitary Sewage

\section{Introduction}

The rapid increase in the population of Brazilian cities and the lack of actions and planning to absorb it with quality, are topics widely approached as reasons for the ills of the urban environment. Human occupation in the spaces quickly and intensely, the result of now obsolete rationality, concentrated industries, services and wealth without equitable distribution of social benefits, reversed the distribution of the population in the country and brought with it numerous conflicts, including environmental ones, to the cities [1]. The growth of the cities has occurred with low coverage of infrastructure networks, such as sewage collection 
and treatment systems. It is common in the early stages of urban growth, when the city's population is still small, the use of pits and sinks. In later stages, municipal managers are unlikely to invest in sewage collection and treatment systems, forcing the population to discharge their sewage into the rainwater drainage network without any treatment [2]. Currently, in Brazilian cities, river waters, in general, are attributed negative aspects, almost always associated with pollution, diseases, odors, among others.

Urban rivers are thought to be responsible for flooding, causing disruption to the population. The Brazilian urbanization model has contributed to this situation in several aspects. Tucci [3] highlights two main flood-generating processes, the first related to the increase of urbanization with unplanned municipal zoning, high soil sealing index and rectification of drainage channels. The constant reduction of soil infiltration makes existing drainage systems unfeasible and makes future networks more expensive according to Giudice and Mendes (2013). Tucci [2] shows that as the urbanization rate increases, the maximum flow increases up to 7 times. The current urbanization model also contributes to flooding by favoring widespread urbanization, pushing residents farther from the old central areas, mostly located near the rivers, impoverishing upstream regions, causing the flow of downstream water (in the central areas) is larger and more concentrated. The second flood-generating process is the natural phenomenon of occupation of the larger riverbeds due to extreme rainfall. It should be noted that floods are natural facts, being a stage present in the common hydrological cycle in regions with or without human occupation [4]. Added to this is the fact that the first process is related to the second, as the more the soil is waterproofed, the greater the volume of water towards the river, which shifts the flood line further, near the occupied areas. These processes occur in the territory because human occupations do not consider the limitations of the environment in which it operates. Disregarding the limitations of the surrounding environment and altering its natural hydrological processes, the emergence of new processes such as floods and contamination, which when trying to remedy intensifies them.

This work presents a real situation by which periurban cities pass through in Brazil, with very little sanitation infrastructure. The lack of adequate sanitation makes that in the densest places of people and buildings, are thrown into the urban rivers garbage, rain and cloacal sewage and others, which greatly lowers the quality of the waters of these rivers.

This paper presents the state of water quality of the Valão dos Bois watercourse, which crosses the city of Seropédica, drawing a parallel with the type of land occupation. It tried to establish quantitative data of the interference that the growth model of the city impacts on the quality of surface water in periurban areas.

\section{Materials and Methods}

Seropédica is a municipality of 82,312 inhabited in the metropolitan region of 
Rio de Janeiro, in Brazil. It is a periurban area with very little sanitary infrastructure. There are less than 5\% of sewage collected and treated [5]. The maintenance of the Valão dos Bois watercourse and its tributaries is an important water management tool in the municipality. It is also important because it contributes to the pollution of Sepetiba Bay, a special ecosystem and socioeconomic region of the state of Rio de Janeiro. Figure 1 shows the location of this town in Brazil and in the Rio de Janeiro State.

This work was carried out in three sequential stages, the first of which was the selection, collection, storage and analysis of water samples from the Valão dos Bois watercourse and its tributaries, totaling 26 points along its $37 \mathrm{~km}$. In this work it was important that water collection points be distributed throughout the entire watercourse. These data aimed to make a preliminary diagnosis and partial framing of the canal in the classes established by Resolution CONAMA No. 357 [6] regarding the parameters of Biological Oxigen Demand (BOD), Chemical Oxigen Demand (COD), Dissolved Total Solids (DTS) and Dissolved Oxigen (DO), temperature (measured on site) and flow (later calculated) were analyzed, and the process of simulation of the self-destructibility of watercourses was performed using the software (SANTOS, 2010) as well as $\mathrm{N}-\mathrm{NH}_{4}^{+}, \mathrm{NO}_{3}^{-}$and $\mathrm{PO}_{4}^{3-}$.

In the second stage, the computer simulation using the software AD'ÁGUA 2.0, the self-purification capabilities of the watercourses, using the data obtained in the analyzes. Since the results of self-purification capabilities for the vast majority of simulated stretches were unsatisfactory, the next step was proceeded.

In the third stage, several computer simulations were performed in order to quantify the maximum flows and sediment transport in the sub-basins of each district in four scenarios. The first in the pre-development state, the second in of the current development, the third in the state of development expected for the municipality and the fourth in the current state of development with the implementation of a point structural solution called infiltration trench, with the purpose

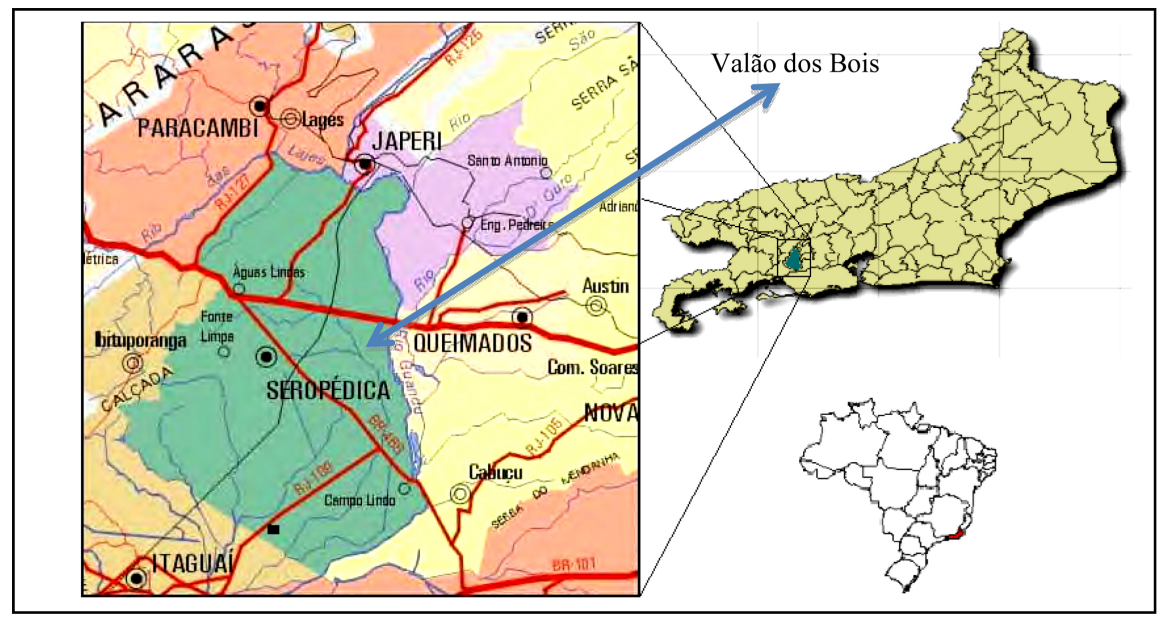

Figure 1. Location of Seropédica. Source: http://seropedicari.com.br/ and http://seropedicaonline.com/ (adapted). 
of reducing runoff and sediment transport to the courses nearby water. This step was performed with the PCSWMM5 software.

The data acquisition and scenario modeling processes followed the sequence with the respective input data were:

- BOD, DO, DTS, Temperature, Flow (section and flow velocity).

- Data for self-purification process simulation: Flow rates, section length, flow velocity, BOD and OD.

- Data for simulation of urbanization scenarios: Sub-basin morphometric data, rainfall data, land use data (waterproofing rate, runoff coefficient), digital basin elevation model, pollutant concentration data by event, control capacity data of infiltration trenches.

For the simulation of all urbanization scenarios, the parameters of the Chicago-based IDF rainfall equation were used for a 4-hour rainfall in return periods of 2, 5, 10, 25 and 50 years for each scenario.

\subsection{Water Sampling}

The selection of sample points was made based on the recommendations of the National Guide for Collection and Preservation of Water and Soil Samples, published by Brazilian National Water Agency [7]. It was firstly selected points located in the outlets of the Valão dos Bois sub-basins that receive runoff water from the main neighborhoods of Seropedica. The other points were selected in the Valão dos Bois just before the confluence with the tributaries coming from the neighborhoods. Thus, we sought to identify the state of the canals that drain each neighborhood as well as the state of the main waterway, the Valão dos Bois, just before the encounter with the channel that drains the neighborhoods.

The third group of points was collected after the mixing zone between the tributary waters and the main channel, in order to quantify the impact of the drained waters of the neighborhoods in Valão dos Bois. Figure 2 shows the map of the Valão dos Bois river basin and its tributaries with the water sampling points.

It is known that the velocity of water flow in a channel varies transversely to the direction of flow as well as to the depth. In order to accurately measure flow velocity, it must divide the channel section at equal distances and measure the velocity at each fraction to a depth set by the device manufacturer. With these velocities homogenized by arithmetic mean, the flow rate is calculated according to Equation (1).

$$
Q=V \times A
$$

On what:

$Q=$ is the homogenized flow of the watercourse in $\mathrm{m}^{3} / \mathrm{s}$.

$V=$ is the homogenized velocity of water flow in $\mathrm{m} / \mathrm{s}$.

$A=$ is the area of the wet section in $\mathrm{m}^{2}$.

\subsection{Surface Water Quality}

Several factors influence the characteristics related to surface water quality. It is 


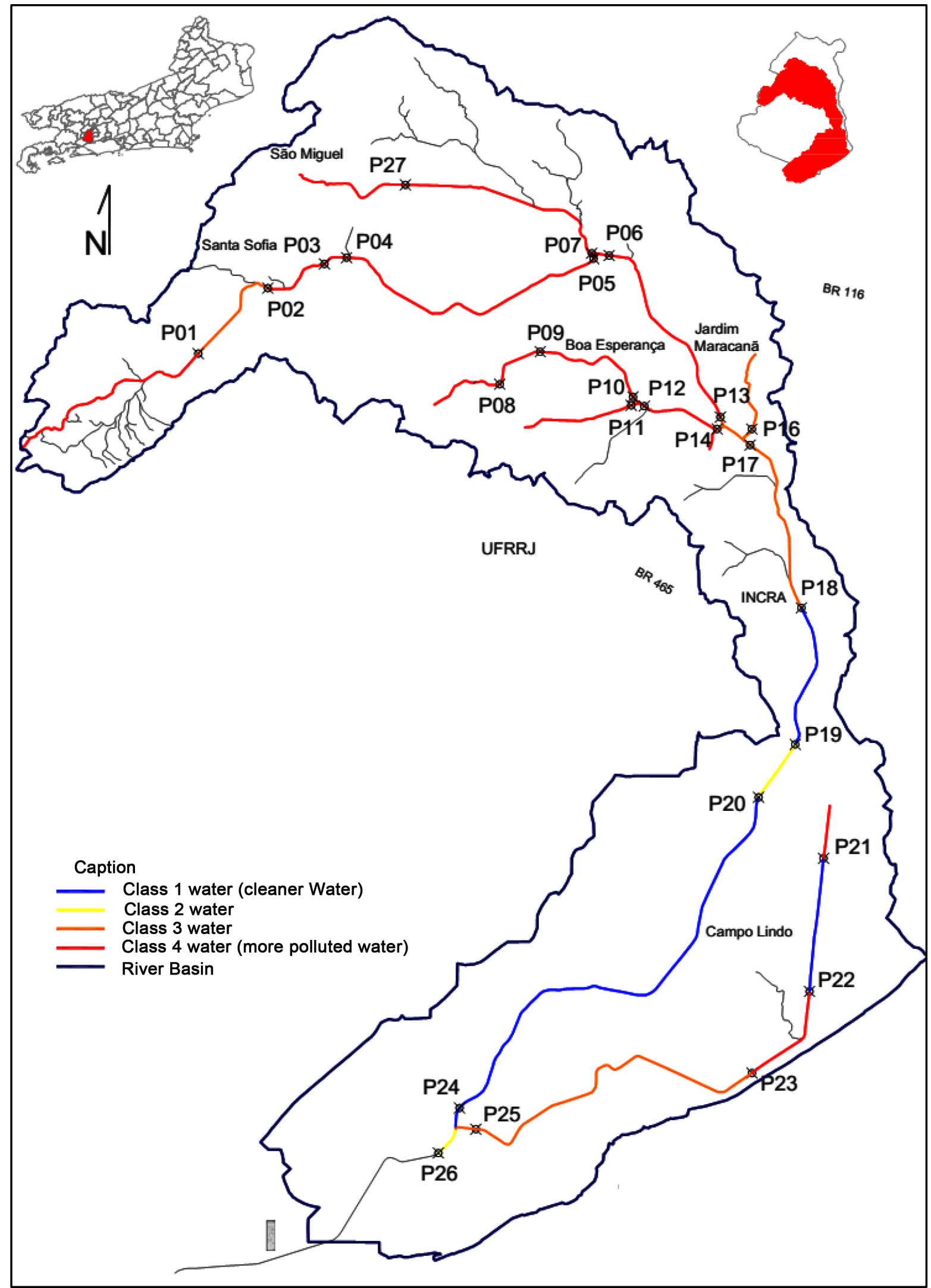

Figure 2. Scheme of location of the points collected at Valão dos Bois watercourse in Seropedica. Source: [8] (adapted). 
highlighted the moment before the rain contact with the soil, and it is emphasized that the water at the moment of the rain varies its chemical characteristics according to the geographic location. At a later time, when the rains begin the runoff process some factors contribute to its quality such as land use, rainfall intensity and duration, the amount of previous days without rain, among others. As shown, the class 4 sections have the highest BOD and TS indexes and the lowest OD indexes. These values are due to the high concentration of organic matter in the waters. According to Righetto, Moeira and Sales [9] the quality of runoff water is directly linked to the characteristics of land use and occupation, which essentially varies from city to city.

\subsection{Scenarios}

Modeling and analysis of scenarios of urban expansion and its changes in the hydrological regime of the watershed were held at the PCSWMM5 2016 Professional 2Dsoftware.

The software combines GIS tools with the models of the Storm Water Management Model SWMM55.

The data required for the initial modeling of the urbanization process are related to the scenarios to be simulated. Thus, to simulate Scenario 1, the pre-development scenario used the following input data:

- vector file of study area watershed.

- vector file of the Expedited Soil Map prepared by the Applied Geoprocessing Laboratory of the Department of Geology/UFRRJ.

- digital elevation model of the watershed under study in raster format based on the level curves.

- morphometric data and land use characteristics within the study sub-basin.

The morphometric and land use data for the watershed requested by the software are RainGage, Area (ha), Width (m), Flow Length (m), Slope (\%), Waterproof $(\mathrm{m}), \mathrm{N}$ waterproof, $\mathrm{N}$ permeable, Dstore waterproof $(\mathrm{mm})$, Zero waterproof (\%), Subarea Routing, Percent Routed, Curb Length, Snow Pack, LID Controls, Groundwater.

For Scenario 2, the current occupation status of the studied sub-basins was simulated and new data were inserted in the model as:

- vector file with land use and occupation information.

- sediment production data in urban areas.

It was simulated by associating the coefficients with the sub-basin area, together with the previously associated soil characteristics and the characteristic pollutant concentrations.

This file was added with information regarding land use and occupation, so each residential block received a waterproofing index according to visual inspection of the aerial image, as well as the areas of streets, pasture, commerce and forest.

The simulated pollutants were Suspended Solids, and Lead and Zinc metals, characteristic of sediments produced in urban areas. Pollutant concentration indices are entered and associated with the respective land use. It has been adopted 
that only transit and residential areas produce and conduct such pollutants.

In Scenario 3, the population projections adopted by Nova CEDAE were used in the context of its sewage project for the municipality of Seropédica and the Sepetiba Bay Sustainable Development Plan, which foresees an average population increase of 3 times in 10 years. years. With this estimate, the impermeable areas were doubled in order to simulate an increase in land occupation and some change of use. Thus, the waterproofing indexes of areas such as Pasture and Forest were also changed from $0 \%$ to $20 \%$. This change aimed to portray the current urbanization pattern of the municipality, which sometimes disregards the preservation of its green areas in the pursuit of economic development.

For Scenario 4, it turned to the current occupation state in order to simulate a solution to reduce runoff and at the same time promote a reduction in sediment transport rates, including pollutants, for watercourses.

Simulation of the installation of infiltration trenches, classified as flood control and/or source pollution control methods or structural flow control methods, was used because it is a solution that is easy to execute and has high removal capacity of sediment.

\section{Results and Discussion}

Figure 3 shows the percentage of waterproofing that Seropédica presents according to Senarios 2 (current occupation) and 3 (future occupation). Table 1 presents some characteristics regarding Scenarios 1, 23 and 4.

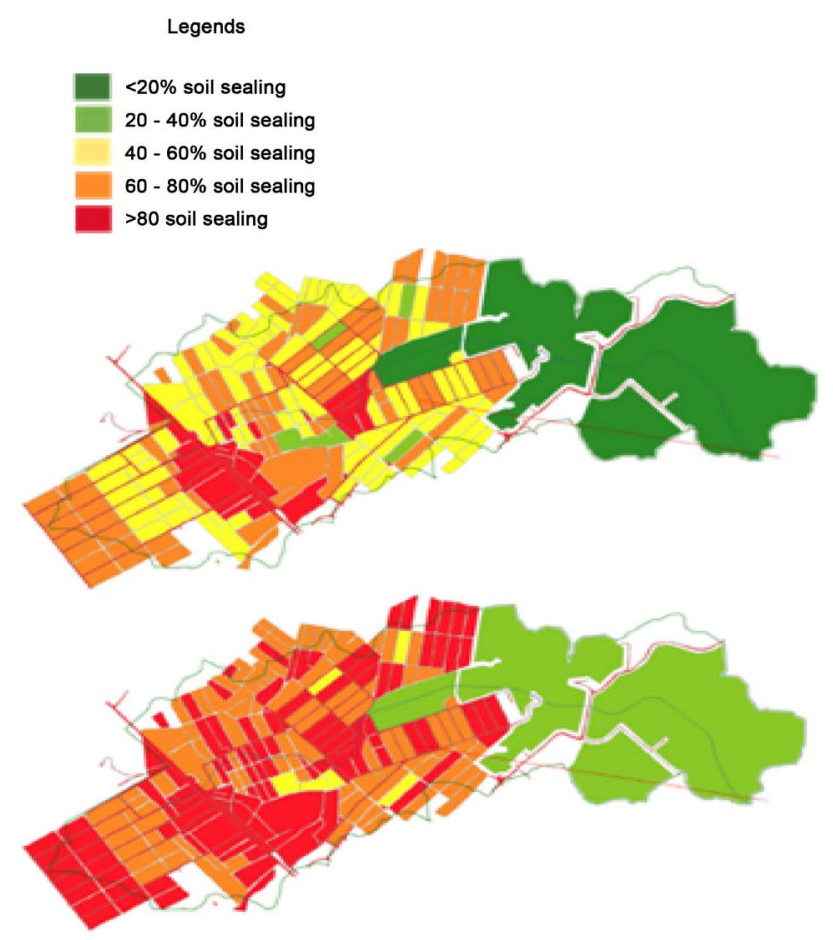

Figure 3. Maps with the percentage of waterproofing with the current (a) Scenery 2, and future (b) Scenery 3, of the soil of the study site. Source: [8]. 
Table 1. Characteristics regarding scenarios 1, 2, 3 and 4.

\begin{tabular}{|c|c|c|c|c|c|}
\hline & $\begin{array}{c}\text { Basin } \\
\text { area }\end{array}$ & $\begin{array}{c}\text { Scenario } 1 \\
\text { Pre } \\
\text { development }\end{array}$ & $\begin{array}{l}\text { Scenario } 2 \\
\text { Current } \\
\text { occupation }\end{array}$ & $\begin{array}{l}\text { Scenario } 3 \\
\text { Future } \\
\text { Occupation }\end{array}$ & $\begin{array}{l}\text { Scenario } 4 \\
\text { Future } \\
\text { Occupation } \\
\text { with BMP }\end{array}$ \\
\hline $\begin{array}{c}\text { Impermeable } \\
\text { areas (\%) }\end{array}$ & & zero & 84.6 & 167.1 & 84.5 \\
\hline $\begin{array}{l}\text { Fraction of the } \\
\text { preciptation } \\
\text { wich stores in } \\
\text { depression in } \\
\text { the watershed } \\
(\%)\end{array}$ & & 72.9 & 69.9 & 52.1 & 76.8 \\
\hline $\begin{array}{l}\text { Fraction of the } \\
\text { that infiltrates } \\
\text { into the } \\
\text { watershed (\%) }\end{array}$ & $\begin{array}{c}13.42 \\
\mathrm{~km}^{2}\end{array}$ & 263.2 & 188.1 & 140.7 & 192.1 \\
\hline $\begin{array}{l}\text { Peak runoff } \\
\left(\mathrm{m}^{3} / \mathrm{s}\right)\end{array}$ & & 19.1 & 82.9 & 139.6 & 64.3 \\
\hline $\begin{array}{l}\text { Suspended } \\
\text { soilids }(\mathrm{kg}) \\
\text { transported } \\
\text { by rain }\end{array}$ & & & $25,237.4$ & $33,279.735$ & $12,126.5$ \\
\hline
\end{tabular}

From the analyzes made we observed high levels of organicload, increase of $500 \%$ BOD, Lower DO content in the most urbanized areas, more in areas with less proofing, possibly industrial dumps between P27 and P07, excessive increase of BOD and decrease of $\mathrm{DO}$ at $\mathrm{P} 08$ and $\mathrm{P} 10$, improvement in water quality at P18 and P19, reduction of organic loads at P21 and P22, infiltration at P22 and P23 and improvement in quality indexes by dilution at P20 and P24. The points may be seen in Figure 1. Majority of analyzed excerpts from the watercourse, present very low levels of water quality, especially in urban areas, improving according to distance themselves from these areas.

As the municipality does not have sewage treatment system, the network of rainwater drainage collector receives it and throw it in the river.

This practice will eventually make the rainwater drainage system works in a way for which it wasn't designed. It does not treat the water volume, instead, pour into the river a total of about $3000 \mathrm{~kg} \mathrm{BOD} /$ per day. However it does not prevent, especially in rural areas, different uses by the population, but not for human consumption.

In the maps, (Figure 1) sections in red have higher rate of BOD and DTS and lower levels of DO, due to high concentration of organic matter in the water.

There is a high concentration of organic load near the occupied areas. The Small increments in impermeable rate, rises much runoff. The infiltration trenches at $0.2 \%$ of the impermeable area were enough to reduce the rates of flow peaks between $8.5 \%$ and $206 \%$ (Table 1). 
For less urbanized areas it is enough to keep the canals. As just $6 \mathrm{~km}^{2}$ of the $114 \mathrm{~km}^{2}$, are impermeable areas, for the less urbanized areas, maintaining the watercourse is enough to establish its quality indexes. For more built-up areas, the adoption of control at source is the most effective action.

It is important that the establishment of guidelines for land-use and soil occupation expanding areas such as infiltration requirement on the part of runoff generated, definition of maximum rates of impermeable soil and concentration of sewage releases at the beginning of the basin, in order to extend the recovery and clean water.

Brazilian's concern for the environment has increased. $47 \%$ of people in Brazil didn't know to mention an environmental problem in their city/neighborhood in 1992 and in 2012 was $11 \%$. In general they know more about environment managing [5]. The greater understanding of environmental processes by the population leads us to believe there was also, a significant increase in the number of people affected by processes arising of environmental impacts.

The socio-environmental aspect of greater prominence in the watercourse is the fresh dump of domestic sewage in the main urban areas and and a soil degradation in a $40 \mathrm{~km}^{2}$ area due to the extraction of sand, activity of great importance for the economy of the municipality and for the supply of the construction market in Rio de Janeiro. During periods of flooding, several sand exploration cavas are flooded and contaminated by the river, when the fragile dikes that protect them are broken. The population attainable by flooding is great [5].

\section{Conclusions}

Seropédica, as many periurban's town in Brazil, despite having a large permeable area, predominantly occupied by pasture, its small urbanized and waterproofed area (about 5\%) strongly impacts, Valão dos Bois, its main watercourse, increases its decaying of organic load indexes, promoting increased flood susceptibility, increased flood peaks, destruction of public assets such as bridges, asphalt disruption and siltation of the drainage network.

In the legislation that regulates the occupation of the municipality's territory, there is no requirement to the soil sealing rate or effective practices of control of runoffs and releases in the channels, or control of diffuse pollution, evidencing an ideology that thinks the actions in the territory in a sectoral and compartmentalized way.

The imminent process of transformation of the territory may contribute to a movement of building land occupation guidelines, which includes cheap and efficient actions to improve the quality of life in the municipality.

The definition of maximum soil waterproofing rates and the requirement for runoff control equivalent to an infiltration trench located in the runoff source are possible and accessible tools within the municipality since its permeable area is still huge.

These tools, while promoting improved canal water quality, show the popula- 
tion that improving the quality of the environment as a whole can be accomplished by summing up the individual improvements on each site. Especially when the population needs to organize to participate in decisions that will affect the city as a whole.

The price of a development that has not historically benefited everyone is the loss of spaces, landscapes and uses for all.

\section{Acknowledgements}

The authors thank the Coordination for the Improvement of Higher Personnel Education (Capes) and the Foundation to support the research at State of Rio de Janeiro (FAPERJ).

\section{Conflicts of Interest}

The authors declare no conflicts of interest regarding the publication of this paper.

\section{References}

[1] Souza, M.L. (2011) ABC dos desenvolvimento urbano. 6a ed., Bertrand Brasil, Rio de Janeiro, 2011.

[2] Tucci, C.E.M. (2002) Gerenciamento da drenagem urbana. Revista Brasileira deRecursos Hídricos, 7, 5-27. https://doi.org/10.21168/rbrh.v7n1.p5-27

[3] Tucci, C.E.M. (1999) Água no meio urbano. In: Rebouças, A.C., et al., Org., Águas doces no Brasil: Capital ecológico, uso e conservação, Escrituras, São Paulo.

[4] Giudice, S.L. and Mendes, J.A.R. (2013) Ações antrópicas e seus impactos nos cursos de água. In: Telles, D.A., Coord., Ciclo ambiental da água: Da chuva à gestão, Blucher, São Paulo, 501 p.

[5] AGÊNcia Nacional de Águas (ANA) (2006) Plano Estratégico de Recursos Hídricos das Bacias Hidrográficas dos Rios Guandu, da Guarda e Guandu Mirim-Relatório do Diagnóstico-Final. GDU-30-0003 RE Revisão 1/1. Superintendência de Planejamento de Recursos Hídricos. Brasília.

http://www.comiteguandu.org.br/downloads/ARTIGOS\%20E\%20OUTROS/Aprese ntacao-PERH-Guandu-05-2017.pdf

[6] Concelho Nacional do Meio Ambiente (CONAMA) (2005) Resolução no 357 de 2005. Dispõe sobre a classificação dos corpos de água e diretrizes ambientais para o seu enquadramento, bem como estabelece as condições e padrões de lançamento de efluentes, e dá outras providências. Data da legislação: 17/03/2005, Publicação DOU no, de 18/03/, 58-63.

http://www2.mma.gov.br/port/conama/legiabre.cfm?codlegi $=459$

[7] Agência nacional de Águas (ANA) (Brasil) (2010) Atlas Brasil: Abastecimento urbano de água: Resultados por estado. Brasília. 72 p. http://atlas.ana.gov.br/Atlas/forms/Home.aspx

[8] Perrut dos Santos, V. (2016) Avaliação dos impactos sócio ambientais na bacia hidrográfica do Valão dos Bois em Seropédica-RJ. Dissertação de Mestrado, Programa de Pós Graduação em Desenvolvimento territorial e políticas públicas, UFRRJ. Seropédica.

[9] Righetto, A.M., Moreira, L.F.F. and Sales, T.E.A. (2009) Manejo de Águas Pluviais 
Urbanas. In: Righetto, A.M., Coord., Manejo de Águas Pluviais Urbanas, ABES, Rio de Janeiro.

https://www.finep.gov.br/images/apoio-e-financiamento/historico-de-programas/pr osab/prosab5 tema 4.pdf 